\title{
Editorial
}

\section{Monti's ECOFIN Discussion Paper}

Sijbren Cnossen, Erasmus University, Rotterdam

In an accessible discussion paper, prepared for an informal meeting of ECOFIN ministers, the European Commission has unfolded its thoughts - presumably, at the behest of its Commissioner for Fiscal Affairs, Dr Mario Monti - on the future of taxation in the Member States of the European Union. According to the Commission, making a decision on that future will make it possible for the EU to meet three interdependent challenges: (1) stabilising the tax revenues of the Member States; (2) ensuring the smooth functioning of the single market; and (3) promoting employment. Mutually reinforcing solutions to these challenges are vital to the success of the third phase of EMU and the Confidence Pact on Employment which is being forged.

The stabilisation of the tax revenues is being jeopardised by 'tax degradation' (sic), which manifests itself in the relocation of tax bases to other countries (a euphemism for the flight of capital and high-value labour) and the underground economy (a euphemism for reduced civicmindedness). Although the total tax level has remained stable in the past 15 years, the tax mix has shifted from taxes on capital to taxes on labour. This process has been furthered by the liberalisation and globalisation of financial markets, which facilitate the avoidance of taxes on capital. Special tax regimes (for example the co-ordination centres in Belgium and the low company tax rate in Ireland - not mentioned in the paper) and the low taxation (or exemption) of interest payments to non-residents erode the capital income base. The tax burden on labour cannot be raised further on account of the negative effects on wage costs and employment. In addition, VATs, excises, and social security contributions suffer from degradation.

The smooth functioning of the single market requires a simpler and less ambiguous VAT regime than that offered by the current deferred-payment system or the clearing mechanism proposed earlier. Essential is that intra-Community transactions are treated identically to domestic transactions. In the field of social security, policy-makers should pay more attention to the non-discriminatory taxation of frontier workers and other non-residents. Businesses rightly complain about the tax barriers that inhibit the free cross-border flow of dividends, interest and royalties; about the differential treatment of permanent establishments (compared to subsidiary companies); and about the inability to offset losses in one Member State against profits in another Member State.

The Commission emphasises that the maintenance of tax revenue yields is essential to meet the convergency criteria for the third phase of EMU, relating to the size of the budgetary deficit, the rate of inflation, and the national debt ratio. In addition, the fight against unemployment is of the utmost importance. Employment can be promoted by reducing the relative over-taxation of labour. This can be achieved by increasing the taxes on consumption (VAT and excises), capital and real property, the environment and energy, and using the proceeds to reduce the tax burden on labour. An interesting idea, according to the Commission, would be to seize the opportunity afforded by the introduction of the definitive VAT regime to increase the weighted average VAT rate by one to three percentage points. The required co-operation, however, is hampered by the unanimity requirement, as well as by the lack of a coherent vision on the economic and social damage that the EU incurs if no decisions are made.

Doing nothing is no solution: it leads to decline. Before the summer, therefore, the Commission will publish a strategic programme for the definitive VAT regime, which will drastically simplify the tax. In any case, further rate approximation is desirable. In the course of the summer, the Commission will issue a communication regarding taxes on income and profits, which will deal specifically with the tax treatment of frontier workers, interest payments to nonresidents, the taxation of permanent establishments, and the question of whether the network of bilateral tax treaties in the EU is still adequate. A one-level minimum tax on capital income deserves consideration, as well as greater transparency in taxation and better administrative cooperation. In the autumn, proposals will follow for the further harmonisation of the excises; moreover, the proposal for an energy tax to reduce carbon dioxide emissions will be reexamined. 
It cannot be denied that the Commission has presented a coherent, albeit concise, tax philosophy. Labour income is certainly taxed highly, possibly too highly, and the tax coverage of capital income is uneven. Changes in the tax mix from taxes on labour to taxes on capital and consumption may reduce the burden on labour and thus improve the functioning of the labour market. Changes in the tax mix will only be effective, however, insofar as the tax burden shifts from the employed to the unemployed - a stringent condition, to be sure.

The question arises whether the Commission's tax philosophy has sufficient economic underpinning to meet the accelerating globalisation of international markets. To stay in the race, the EU must increase its labour and capital productivity. This demands higher net remunerations, especially of labour, and greater incentives to participate (more intensively) in the production process. Viewed in this light, employment can only be promoted by tax relief and reductions in income transfer payments. The objectives of revenue stabilisation and employment promotion or the smooth functioning of the single market are partially inconsistent. Instead of being mutually reinforcing, the proposed measures might be mutually conflicting. Taxes on consumption and capital may also be borne by labour. Moreover, the flight of capital and highvalue labour occurs precisely because the tax burden is so high. The stabilisation of tax yields (a euphemism for maintaining the total tax burden) should promote the planned introduction of the EMU, but it may not help further the employment objective, even if otherwise desirable changes in the tax mix are effected. 